\title{
PENGOLAHAN DAN PENYAJIAN MAKANAN NEGARA MALAYSIA
}

\author{
Maryam Qonitahs \\ Yola Salsabila \\ Program Studi Pendidikan Kesejahteraan Keluarga \\ Fakultas Pariwisata Dan Perhotelan \\ Universitas Negeri Padang \\ Maryamqoni@gmail.com \\ Yolasalsabilaa24@gmail.com
}

\begin{abstract}
Abstrak
Makanan di Malaysia melambangkan rakyatnya yang berbilang kaum. Makanan-makanan tersebut pada asalnya berasal dari berbagai negeri dan suku kaum, tetapi kini telah disediakan sebagai hidangan biasa umum di Malaysia. Sebagai negara kosmopolitan, Malaysia juga mempunyai budaya yang agak unik. Gabungan kaum Melayu, Cina dan India Cina berjaya menyatukan berbagai hidangan kepada 'hidangan Malaysia' dan menjadikan ia sebagai satu tarikan kepada pelancong luar. Penduduk di Malaysia ini juga dikatakan banyak menghabiskan masa di meja makanan dan menjadikan masa menikmati hidangan itu sebagai aktiviti kebangsaan. Kaum Cina, India dan Melayu di Malaysia ini sentiasa kreatif, berganding bahu mereka masakan baru dengan menggabungkan pinjam meminjam tradisi budaya masing-masing. Dengan ini lahirlah nasi ayam, mi mamak, mi kari dan lain-lain.
\end{abstract}

Kata kunci: Pengolahan Makanan Malaysia, Penyajian Makanan Malaysia, Makanan Khas Malaysia 


\section{Pendahuluan}

Masakan Malaysia dipengaruhi oleh berbagai budaya dari seluruh dunia. Sebagian besar penduduk Malaysia kasar dapat dibagi di antara tiga kelompok etnis utama : Melayu, Cina dan India. Sisanya terdiri dari Peranakan dan masyarakat Kreol Eurasia, Orang Asli Semenanjung Malaysia, masyarakat adat dari Sabah dan Sarawak di Malaysia Timur, serta sejumlah besar pekerja asing dan ekspatriat. Sebagai hasil dari migrasi sejarah, penjajahan oleh kekuatan asing, dan posisi geografis di kawasan Asia Tenggara yang lebih luas, gaya kuliner Malaysia pada hari ini terutama melange tradisi dari bahasa Melayu -nya, Cina, India, Indonesia dan etnis warga Borneo, dengan berat terhadap pengaruh cahaya dari Thai, Arab, Portugis, Belanda, dan Inggris masakan untuk beberapa nama. Hal ini mengakibatkan sebuah simfoni rasa, membuat masakan Malaysia yang sangat kompleks .

Karena Semenanjung Malaysia berbagi sejarah budaya umum dengan Republik Singapura, adalah umum untuk menemukan versi hidangan yang sama di kedua sisi perbatasan terlepas dari tempat asal. Malaysia juga berbagi sejarah, budaya, dan etnis hubungan dekat dengan Indonesia. Daerah Melayu yang berbeda semua dikenal untuk hidangan unik atau tanda tangan mereka Terengganu dan Kelantan untuk mereka Nasi Dagang, Nasi kerabu dan Keropok lekor, Negeri Sembilan untuk perusahaan berbasis piring lemak, Pahang untuk tempoyak gulai nya, Kedah untuk perusahaan utara gaya Asam laksa, Malaka untuk pedas Asam pedas, Riau untuk patin ikan mereka ( ikan patin ) piring, Gulai ikan patin dan Asam Pedas patin ikan, Melayu Deli Medan Sumatera Utara untuk mereka Nasi goreng teri Medan ( Medan ikan teri nasi goreng ) dan Gulai Ketam ( gulai kepiting ) dan Brunei untuk hidangan Ambuyat unik .

Ciri utama dalam masakan tradisional Melayu tidak diragukan lagi murah hati penggunaan rempah-rempah. Santan juga penting dalam memberikan hidangan Melayu yang kaya, karakter krim mereka. Landasan lain adalah belacan ( terasi ), 
yang digunakan sebagai dasar untuk sambal, saus kaya atau bumbu yang terbuat dari terasi, cabai, bawang dan bawang putih. Malay memasak juga memanfaatkan berlimpah serai dan lengkuas. Hampir setiap makanan Melayu disajikan dengan nasi, makanan pokok di banyak budaya Asia Timur lainnya. Meskipun ada berbagai jenis masakan di makan Melayu, semua disajikan sekaligus, bukan dalam kursus. Makanan yang dimakan hati-hati dengan jari tangan kanan, tidak pernah dengan kiri yang digunakan untuk wudhu pribadi, dan Melayu jarang menggunakan peralatan.

Tidak jelas kapan tradisi kuliner Melayu terbentuk, tetapi catatan paling awal dari tradisi adalah dari abad ke-15 ketika Kesultanan Malaka menjadi pusat perdagangan penting di kepulauan Melayu. Warisan paling penting Malaka berasal dari keterlibatannya dalam perdagangan rempah-rempah, keterbukaan terhadap bahan-bahan dan teknik kuliner diperkenalkan oleh orang asing terutama orangorang Arab, Persia, Cina dan India dan budidaya dari keahlian memasak eklektik kaya. Malaka juga menjadi katalis untuk pengembangan dua budaya kuliner lainnya yang kaya dan unik yang merupakan perpaduan dari Melayu dengan tradisi Cina dan Eropa, masakan masing-masing dikenal sebagai Nyonya dan Eurasia. Pada abad sebelum dan sesudah Malaka, ada kelompok-kelompok Melayu non dari Bugis, Jawa untuk Minangkabau yang diserap ke dalam masyarakat Melayu pada waktu yang berbeda, dibantu oleh kesamaan gaya hidup dan agama umum, dan memiliki berbagai tingkat pengaruh pada makanan Melayu.

Nasi lemak, nasi yang dimasak dalam santan yang kaya mungkin adalah hidangan paling populer di mana-mana di kota dan desa-desa Melayu. Nasi lemak dianggap sebagai hidangan nasional Malaysia. Contoh lain adalah Ketupat atau nasi himpit, ketan dikompresi nasi di dedaunan palem, sangat populer terutama selama Hari Raya atau Idul Fitri. Berbagai daging dan sayuran bisa dibuat menjadi Gulai atau Kari, jenis hidangan kari dengan variasi rempah-rempah campuran yang jelas menampilkan pengaruh India sudah diadopsi oleh orang-orang Melayu sejak zaman kuno. 
Karena sebagian besar orang Melayu beragama Islam, masakan Melayu mengikuti hukum diet Islam halal ketat. Asupan protein yang sebagian besar diambil dari daging sapi, kerbau, kambing, dan daging domba, dan juga termasuk unggas dan ikan. Pork dan setiap daging non halal, juga alkohol dilarang dan absen dari makanan sehari-hari Melayu. Laksa, hibrida Melayu dan Peranakan masakan Cina juga merupakan hidangan populer. Masakan Melayu juga mengadopsi masakan tradisi beberapa tetangga mereka, seperti rendang diadopsi dari Minangkabau di Sumatera, dan sate dari Jawa, namun orang Melayu telah mengembangkan rasa khas mereka sendiri dan resep.

\section{Pembahasan}

\section{Tata cara penyajian makanan Malaysia}

Penyajian makanan di Malaysia yaitu: makanan di hidang serentak (kecuali bankuet Cina) dan setiap individu akan dihidangkan dengan nasi dan mereka akan memilih lauk pauk sendiri. Tata cara makan orang Malaysia sama dengan orang India dan orang Melayu, yaitu menggunakan tangan dan kaum Cina menggunakan penyepit. Menggunakan tangan juga mempunyai etika tersendiri. Kita hanya menggunakan tangan kanan dan ujung jari saja. Telapak tangan tidak digunakan dan harus kelihatan bersih. kita akan diberi air basuh tangan oleh tuan rumah dan di restoran-restoran disediakan sinki basuh tangan dan sabun. Kita tidak dibenarkan mengambil makanan dari pinggan hidang dengan tangan. Kita bisa menggunakan sendok yang disediakan dengan mengambilnya dengan tangan kiri. Sebaiknya kita mengambil makanan terdekat dengan posisi kita duduk sebelum mengambil makanan yang agak jauh dari jangkauan dan tidak banyak bicara, jangan bicara ketika mulut masih penuh dan terakhir tidak mengunyah terlalu kuat/kerass.

Ketika berkunjung ke rumah orang, apabila tuan menghidangkan makanan atau minuman, janganlah menolaknya. Jika kenyang sekalipun kita hendaklah menjamah sedikit hidangan yang disajikan itu. Setelah makanan dihidangkan, pastikan orang yang lebih tua duduk dahulu kemudian diikuti oleh 
orang muda pula mengambil tempat masing-masing. Anak gadis pula dikehendaki menyanduk nasi ke dalam pinggan orang yang lebih tua. Biarkan orang yang lebih tua mengambil makanan dahulu kemudian barulah diikuti oleh orang muda. Tidak sopan jika membiarkan orang yang lebih tua makan sisa orang muda. Oleh karena itu, sesetengah orang membuat peraturan supaya orang muda makan berasingan daripada orang yang lebih tua atau orang tua makan dahulu daripada orang muda. Pastikan sudu, piring atau mangkuk tidak berlaga dan berbunyi ketika menyenduk. Ketika orang lain sedang makan janganlah menghembus hingus, berdahak atau berludah dengan makan. Jangan makan terlalu kenyang. Jangan pergi ke rumah orang pada waktu makan dan waktu maghrib. Ini mengganggu tuan rumah kerana mungkin dia telah memasak makanan cukup untuk keluarganya saja. Orang Melayu memang terkenal dengan sopan santun mereka sejak zaman dahulu lagi.

\section{Alat yang digunakan untuk mengolah oleh masyarakat Malaysia}

Kehidupan masyarakat Melayu juga tidak dapat melepaskan diri dari peralatan rumah tangga, terutama peralatan dapur atau peralatan masakmemasak. Peralatan rumah tangga khas Melayu yang pernah dipakai atau masih dipakai, antara lain : Periuk (periuk bertutup, periuk gerenseng, periuk tanah, dan periuk bertutup bertelinga dua), kuali, dan belanga. Alat-alat ini secara umum digunakan untuk memasak masakan sehari-hari, namun ada juga alat memasak ini yang digunakan secara khusus, misalnya belanga dan periuk tanah. Belanga digunakan untuk memasak gulai dan periuk tanah digunakan untuk merebus obat-obatan. Lesung batu, nyiru, Ayak, tapis(an), Sudip, sendok, sudu, kukur kelapa,tudung saji, lekar, talam, Ceret (ceret memiliki beberapa macam, seperti tekoh, torak atau kendi, ceret labu, labu duduk). Adapun alat modern yang dipakai orang Malaysia pada umumnya sama hanya bentuknya saja yang berbeda. 


\section{Bumbu dan rempah dari Malaysia}

Ciri khas masakan Malaysia adalah pedas (india), gurih (santan), dan manis (cina). Santan merupakan bahan asas dalam masakan melayu. Santan digunakan dalam segala jenis gulai atau masak lemak. Bahan perasa (seasonings) dalam masakan Melayu di bagi menjadi dua, yaitu: rempah basah dan rempah kering. Rempah basah yaitu bahan yang ditumbuk dengan batu lesung, seperti: bawang, halia, bawang putih dan cili.

Rempah kering, seperti: biji ketumbar, jintan, buah pelaga, kayu manis dan lain-lain. Rempah ini selalu di sangai (digoreng tanpa minyak) terlebih dahulu sebelum ditumbuk atau dikisar. Orang Melayu juga banyak menggunakan bahan-bahan herbal, seperti: serai, daun pandan, daun limau purut, daun kemangi, bunga kantan, kunyit, lengkuas dan buah pala.

\section{Makanan khas negara Malaysia}

Makanan asli melayu ini sebenarnya mirip dengan nasi uduk di Indonesia, yaitu nasi yang di aron dengan santan kelapa. Yang membedakan adalah makanan ini dihidangkan dengan ikan teri kering, kacang dan mentimun dan diberi sambal goreng merah. Pada setiap tempat yang menyediakan nasi lemak, kita bisa memilih berbagai macam lauk, yang paling favorit adalah ayam goreng, telur asin, rendang dan cumi dimasak sambal. Banana Leaf Rice yang terkenal adalah di Restoran Nirvana Maju, Bangsar dan Restoran Lotus di Jalan Gassing Petaling Jaya. Yong Tau Fu, Makanan yang berasal dari suku Hakka China terutama terbuat dari tahu yang telah diisi dengan daging giling campuran atau pasta ikan (surimi). Variasi makanan ini termasuk sayuran dan jamur disatukan dengan daging giling atau surimi.

Kalau di Indonesia mungkin mirip dengan bakso tahu. Yong tau fu dapat dimakan dalam berbagai cara, baik kering dengan saus atau disajikan sebagai hidangan sup. Nasi ayam adalah hidangan yang diadaptasi dari imigran Cina awal berasal dari provinsi Hainan di Cina selatan. Hal ini dianggap salah satu hidangan nasional Singapura dan Malaysia. Cara membuatnya ayam disiapkan dalam metode tradisional Hainan dengan menyeduh seluruh ayam pada suhu 
mendidih dalam kaldu daging babi dan tulang ayam, menggunakan kembali kaldu berulang-ulang dan hanya menambah air bila diperlukan, Kaldu inilah yang juga dibuat untuk menanak nasi. Penyajiannya nasi kaldu ayam dan dagingnya ditambah dengan nam, saus, daun bawang, bawang putih cincang, jahe, minyak wijen dan kecap.

\section{Simpulan dan saran Simpulan}

Malaysia adalah sebuah negara federasiyang terdiri dari tiga belas negara bagian dan tiga wilayah persekutuan di Asia Tenggara dengan luas 329.847 km persegi. Ibukotanya adalah Kuala Lumpur. Suku Melayu menjadi bagian terbesar dari populasi Malaysia. Penduduk Malaysia terdiri dari: Bangsa Melayu (59\%), Bangsa Cina (32\%),dan Bangsa India (8\%). Agama yang digunakan sebagian besar adalah islam. Mata pencaharian penduduk: pertanian dan perkebunan, pertambangan dan perdagangan.

Sejarah masakan Malaysia merupakan pembudayaan dari kaum melayu, india dan cina. Masakan nyonya sangat diminati oleh berbagai kaum di Malaysia. Keturunan nyonya berasal dari kaum Cina dan Amoy (Xiamen) dan Fukian. Ciri khas masakan Malaysia adalah pedas (india), gurih (santan), dan manis (cina). Penyajian makanan di Malaysia yaitu: makanan di hidang serentak (kecuali bankuet Cina) dan setiap individu akan dihidangkan dengan nasi dan mereka akan memilih lauk pauk sendiri. Tata cara makan orang Malaysia sama dengan orang India dan orang Melayu, yaitu menggunakan tangan dan kaum Cina menggunakan penyepitAdapun makanan khas Negara Malaysia seperti ayam buah keluak, nasi kandar, laksa penang, penang char kwe teow, ipoh hor fun dan nasi lemak

\section{Saran}

Menyadari bahwa penulis masih jauh dari kata sempurna, kedepannya penulis akan lebih fokus lagi dalam menjelaskan tentang makalah di atas dengan sumber-sumber yang lebih banyak yang tentunya dapat di pertanggung jawabkan. Untuk saran bisa berisi kritik atau saran terhadap penulisan juga bisa 
untuk menanggapi terhadap kesimpulan dari bahasan makalah yang telah di jelaskan. Untuk bagian terakhir dari makalah adalah daftar pustaka. Pada kesempatan lain akan saya jelaskan tentang daftar pustaka makalah.

\section{Daftar Pustaka}

Cemara. Ilmu Pengetahuan Sosial. Surakarta: Putra Nugraha

Norani Sidek, Madya. 2005. Pembudayaan Makanan Malaysia. Selangor: Universiti Teknologi MARA.

Zifanhea, crhisterra (2007) rempah rahasia yang bikin masakan sedap.Kuala Lumpur: MDC Publishers \& Printers Sdn Bhd, 2002

Sari.2007: Jurnal Institut Bahasa, Kesusateraan dan Kebudayaan Melayu, Universiti Kebangsaan Malaysia, Volumes 5-10

Zulfikar, D (2019). Pengolahan dan penyajian Makanan Malaysia. OSF.IO/INARxiv

Zulfikar, D (2019). Pengolahan dan Penyajian Makanan Negara Thailand. OSF.IO/INA-Rxiv 